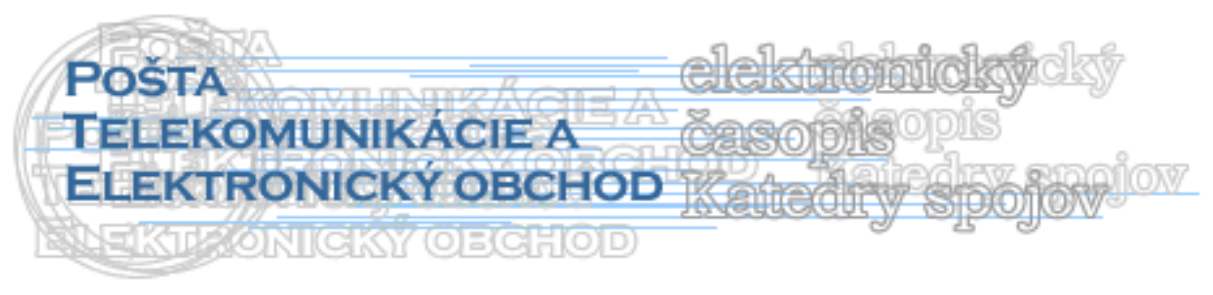

\title{
PRÁCA S ALTERNATÍVNYM ZNAKOM
}

\author{
Ol'ga Zajasenská ${ }^{1}$
}

V poslednej dobe často uplatňovaná špecifická forma štatistického zistovania, ktorou je anketa, v značnej miere pri vybraných štatistických jednotkách zist'uje vlastnosti, ktoré možno vyjadrit' len slovne. znak".

Štatistická terminológia má pre vlastnost' takéhoto typu ustálený termín „kvalitatívny

Hlavná odlišnost' kvalitatívneho znaku od znaku kvantitatívneho je v tom, že jednotlivé varianty kvalitatívneho znaku - vyjadrené slovne - nemožno pred zhrnutím jednoznačne usporiadat'. Nemôže íst' teda o rozdelenie početností, pretože rozdelenie je spojené s určitou polohou, variabilitou, šikmost'ou a špicatost'ou. Pri množnom kvalitatívnom štatistickom znaku t'ažko hovorit' o jeho polohe, variabilite, určitom tvare. Nemajú žiaden zmysel ani kumulované početnosti.

Určité objektívne zaradenie variantov množného kvalitatívneho štatistického znaku je možné až po zhrnutí. Najlepší prehl'ad obyčajnej získame tak, že zarad'ujeme varianty kvalitatívneho znaku od najčastejšie sa vyskytujúcich po tie, ktoré majú najmenší výskyt, alebo opačne.

Zhrnuté údaje o kvalitatívnom znaku zobrazujeme graficky alebo stĺpcovým štrukturálnym diagramom, alebo výsekovým diagramom.

Zvláštnym prípadom kvalitatívneho štatistického znaku je alternatívny kvalitatívny znak. Jeho zvláštnost' spočíva $\mathrm{v}$ tom, že môže byt' l'ahko kvantifikovaný, to znamená prevedený na znak kvantitatívny, a to tak, že sa jeho jednému variantu prisúdi hodnota 1 a druhému variantu hodnota 0 . O takom znaku sa potom hovorí ako o nula - jednotkovej veličine. Jeho spracovanie pozostáva s jednoduchého spočítania jednotiek s jedným variantom znaku (ak poznáme rozsah súboru).

Je zrejmé, že na alternatívny znak možno upravit' a potom l'ahko kvantifikovat' ktorýkol'vek množný kvalitatívny znak, a to tak, že za alternatívu 1 zvolíme tú obmenu (ten variant), ktorá nás predovšetkým zaujíma.

Súhrn všetkých ostatných obmien (variantov) daného znaku potom tvorí alternatívu 0.

Zo zovšeobecňujúcich charakteristík pri alternatívnom znaku je reálny výpočet aritmetického priemeru a disperzie.

Pre priblíženie výpočtu poslúži tabul'ka, zostavená pre nula - jednotkovú veličinu (tab. č. 1).

\footnotetext{
${ }^{1}$ doc. Ing. Ol'ga Zajasenská, Csc. Katedra spojov, Fakulta prevádzky a ekonomiky dopravy a spojov, Žilinská univerzita v Žiline, Univerzitná 1, 01026 Žilina, Slovenská republika, tel.: +421415133111 , fax: +421415655615
} 
Tab. ̌̌. 1

\begin{tabular}{|c|c|c|c|}
\hline Hodnoty znaku $\left(x_{i}\right)$ & Početnosti $\left(n_{i}\right)$ & $x_{i} \cdot n_{i}$ & $x_{i}^{2} \cdot n_{i}$ \\
\hline 1 & $n_{1}$ & $1 \cdot n_{1}$ & $n_{1}$ \\
\hline 0 & $n_{2}$ & $0 \cdot n_{2}$ & 0 \\
\hline Spolu & $n$ & $n_{1}$ & $n_{1}$ \\
\hline
\end{tabular}

Aritmetický priemer, ktorý počítame v tvare váženom, pri využití symboliky z tabul'ky č. 1 bude predstavovat':

$$
\bar{x}=\frac{1 \cdot n_{1}+0 \cdot n_{2}}{n_{1}+n_{2}}=\frac{n_{1}}{n} ;
$$

Aritmetický priemer nula - jednotkovej veličiny sa teda rovná relatívnej početnosti výskytu alternatívy, ktorá nás zaujíma.

Charakteristika variability, ktorou je disperzia (rozptyl) pri využití rozdielového vzt'ahu $S_{x}^{2}=\overline{x^{2}}-\bar{x}^{2}$ bude podl'a symboliky tab. č. 1 predstavovat':

$$
S_{x}^{2}=\frac{n_{1}}{n}-\left(\frac{n_{1}}{n}\right)^{2}=\frac{n_{1}}{n}\left(1-\frac{n_{1}}{n}\right)=\frac{n_{1}}{n} \cdot \frac{n-n_{1}}{n}=\frac{n_{1}}{n} \cdot \frac{n_{2}}{n} .
$$
alternatív.

Rozptyl alternatívneho znaku sa teda rovná súčinu relatívnych početností obidvoch

Pri skúmaní sily závislosti medzi alternatívnymi znakmi sa používajú koeficienty, ktoré sú vypočítavané $\mathrm{z}$ údajov tzv. kontingenčnej hodnoty, v ktorej každé z políčok zodpovedá rozdeleniu podl'a alternatív jedného aj druhého znaku.

Najrozšírenejšie charakteristiky sily závislosti pri alternatívnych znakoch sú:

- koeficient kontingencie;

- koeficient asociácie;

- koeficient koligácie.

Ak použijeme symboliku, zavedenú pre políčka kontingenčnej tabul'ky:

\begin{tabular}{c|c|c|}
\multicolumn{2}{c}{$y$} \\
\hline $\mathbf{a}$ & $\mathbf{b}$ \\
\cline { 2 - 3 } \multicolumn{1}{c}{$\mathbf{c}$} & $\mathbf{d}$ \\
\cline { 2 - 3 } & &
\end{tabular}

potom tieto koeficienty vypočítame podl’a nasledovných výrazov:

$$
\begin{aligned}
& \text { Koeficient kontingencie }=\frac{a d-c b}{\sqrt{(a+b)(c+d)(a+c)(b+d)}} ; \\
& \text { Koeficient asociácie }=\frac{a d-c b}{a d+c b} ; \\
& \text { Koeficient koligácie }=\frac{\sqrt{a d}-\sqrt{c b}}{\sqrt{a d}+\sqrt{c b}} .
\end{aligned}
$$


Uvedené výrazy (3), (4), (5) sa od seba málo líšia a t’ažko uprednostnit' niektorý z nich. Literatúra neuvádza, za akých okolností ktorý z nich použit'.

Najčastejšie je používaný koeficient kontingencie. V rade učebníc z teórie štatistiky sa tento koeficient nazýva koeficientom asociácie. Avšak dosadzované kombinácie v menovateli charakteristiky môžu sa javit' absurdnými a nejestvujú dôkazy, že zmena alternatívnych znakov má lineárny priebeh. Stojí za zmienku, že pri zámene poradia skupín v riadkoch alebo stĺpcoch dochádza k zmene znamienka charakteristík, teda informácia bude o opačnom smere závislosti. Alternatívnost' však znamená rovnaký predpoklad obidvoch variantov bez toho, na ktorom mieste a v akom poradí sa nachádzajú.

Pre kvantifikovanie vzt'ahu dvoch alternatívnych znakov sa javí ako možné použitie charakteristiky, ktorá zohl'adňuje vel'kost' podielov skutočných disperzií k disperziám rovnomenného rozdelenia alternatívnych znakov podl’a výrazu:

$$
K_{A}=1-\frac{\prod S_{i j}^{2}}{\left(S_{i j_{R}}^{2}\right)^{4}}
$$

kde v čitateli výrazu je súčin disperzií alternatívnych znakov podl'a riadkov (i) a podl'a stípcov $(j)$ a v menovateli vel'kost' disperzie pri rovnomennom rozdelení podl'a obidvoch znakov.

Pre rovnomenné rozdelenie alternatívnych znakov platí stálost' disperzie, ktorá sa rovná 0,25 .

Výpočet charakteristiky sily závislosti podla (6) je pomerne jednoduchý a ponímanie jeho zložiek nevyvoláva pochybnosti a t’ažkosti.

Pre ilustráciu vyššie uvedených konštatovaní sú použité údaje sprehl'adnené v tab. č. 3 (Kildišev, G. S.; Ovsinenko, B. J.: Všeobecná teória štatistiky, Štatistika, Moskva 1980, st. $244-246)$

Tab. č. 2 Rozdelenie osôb podl'a zdravotného stavu a fyzickej sily

\begin{tabular}{|c|c|c|c|}
\hline \multirow{2}{*}{$\begin{array}{l}\text { Skupiny podl'a } \\
\text { fyzickej sily }\left(x_{i}\right)\end{array}$} & \multicolumn{2}{|c|}{ Skupiny podl'a zdravotného stavu $\left(y_{j}\right)$} & \multirow[b]{2}{*}{ Spolu } \\
\hline & $\begin{array}{l}\text { zdraví } \\
\left(y_{1}\right) \\
\end{array}$ & $\begin{array}{l}\text { vyžadujúci liečenie } \\
\left(y_{2}\right)\end{array}$ & \\
\hline Silní $\left(x_{1}\right)$ & 178 & 79 & 257 \\
\hline Slabí $\left(x_{2}\right)$ & 92 & 131 & 223 \\
\hline Spolu & 270 & 210 & 480 \\
\hline
\end{tabular}

Intenzita vzt’ahu medzi alternatívnymi znakmi predstavuje:

- $\quad$ podl'a (3)

$$
k=\frac{(178 \times 131)-(92 \times 79)}{\sqrt{270 \times 210 \times 257 \times 223}}=0,281
$$

- $\quad$ podl'a (4)

$$
k=\frac{(178 \times 131)-(92 \times 79)}{(178 \times 131)+(92 \times 79)}=0,525
$$


- $\quad$ podl'a (5)

$$
k=\frac{\sqrt{(178 \times 131)}-\sqrt{(92 \times 79)}}{\sqrt{(178 \times 131)}+\sqrt{(92 \times 79)}}=0,283 .
$$

Ak by skúmaný súbor podl'a alternatívnych znakov mal rovnomenné rozdelenie, potom kvantitatívne zastúpenie (Tab. č. 4) by predstavovalo:

Tab. č. 3 Rovnomenné rozdelenie osôb podl'a zdravotného stavu a fyzickej sily

\begin{tabular}{|c|c|c|c|}
\hline \multirow{2}{*}{$\begin{array}{l}\text { Skupiny podlaa } \\
\text { fyzickej sily }\left(x_{i}\right)\end{array}$} & \multicolumn{2}{|c|}{ Skupiny podla zdravotného stavu $\left(y_{j}\right)$} & \multirow[b]{2}{*}{ Spolu } \\
\hline & $\begin{array}{l}\text { zdraví } \\
\left(y_{1}\right)\end{array}$ & $\begin{array}{l}\text { vyžadujúci liečenie } \\
\left(y_{2}\right)\end{array}$ & \\
\hline$\left(x_{1}\right)$ & 120 & 120 & 240 \\
\hline$\left(x_{2}\right)$ & 120 & 120 & 240 \\
\hline Spolu & 240 & 240 & 480 \\
\hline
\end{tabular}

Podl'a (2) z údajov tab. č. 4 sa potvrdzuje konštantnost' disperzie:

$$
S_{i j_{R}}^{2}=\frac{120}{240} \times \frac{120}{240}=0,25 .
$$

Pri dvoch alternatívnych znakoch a ich kombináciách treba uvažovat' $\mathrm{s}$ jej štvornásobným výskytom.

Intenzita vzt'ahu podl'a (6) bude:

$$
K_{A}=1-\frac{0,25 \times 0,25 \times 0,25 \times 0,25}{(0,25)^{4}}=1-1=0 ；
$$

Teda pri rovnomennom rozdelení súboru podl'a alternatívnych znakov závislost' medzi nimi nejestvuje.

Pri akceptovaní rozdelenia podl'a tab. č. 3 skutočné disperzie alternatívneho znaku sa budú líšit' od konštantnej a vel'kost' podielov bude vplývat' na intenzitu vzt'ahu alternatívnych znakov.

Ak údaje tab. č. 3 uvedieme v štrukturálnej skladbe a podl'a (2) vypočítame skutočné

\begin{tabular}{|c|c|c|c|c|}
\hline \multirow{2}{*}{$\begin{array}{l}\text { Skupiny podl'a } \\
\text { fyzickej sily }\left(x_{i}\right)\end{array}$} & \multicolumn{2}{|c|}{ Skupiny podl'a zdravotného stavu $\left(y_{j}\right)$} & \multirow[b]{2}{*}{ Spolu } & \multirow{2}{*}{$\begin{array}{c}\text { Disperzia } \\
S_{x / y}^{2} \\
\end{array}$} \\
\hline & $\begin{array}{l}\text { zdraví } \\
\left(y_{1}\right)\end{array}$ & $\begin{array}{l}\text { vyžadujúci liečenie } \\
\left(y_{2}\right)\end{array}$ & & \\
\hline Silní $\left(x_{1}\right)$ & 0,692 & 0,624 & 1,000 & 0,213 \\
\hline Slabí $\left(x_{2}\right)$ & 0,412 & $0,624 \quad 0,598$ & 1,000 & 0,246 \\
\hline Spolu & 1,000 & 1,000 & $\mathrm{x}$ & $\mathrm{x}$ \\
\hline Disperzia $S_{y / x}^{2}$ & 0,225 & 0,235 & $\mathrm{x}$ & $\mathrm{x}$ \\
\hline
\end{tabular}
disperzie, získame výsledky, ktoré sú uvedené v tab. č. 5:

Tab. č. 4 Štruktúra a disperzie súboru pri alternatívnych znakoch 
Využitie údajov tab. č. 5 vo vzt'ahu (6) umožní vypočítat' intenzitu vzt'ahu medzi alternatívnymi znakmi:

$$
K_{A}=1-\frac{0,213 \times 0,246 \times 0,225 \times 0,235}{(0,25)^{4}}=1-0,709=0,291
$$

Výsledok potvrdzuje slabú intenzitu vzt’ahu medzi alternatívnymi znakmi. Výpočet je pomerne jednoduchý, založený na prvkoch, ktorých obsah je logický. 